\title{
Comparative Sectoral Efficiency in the Fight Against Poverty and Unemployment in Burkina Faso
}

\author{
Patrice Rélouendé Zidouemba \\ Correspondence: Patrice Rélouendé Zidouemba, Rural Development Institute, Nazi Boni University, Bobo-Dioulasso, \\ Burkina Faso.
}

Received: January 29, 2017

doi:10.11114/aef.v5i2.2953
Accepted: February 24, $2018 \quad$ Available online: February 27, 2018

URL: https://doi.org/10.11114/aef.v5i2.2953

\begin{abstract}
In this paper, we construct an economy-wide recursive dynamic model for Burkina Faso to explore the impact of scaling up public capital in different aggregate sectors. While several researchers emphasize the importance for sub-Saharan African countries of giving higher priority to agriculture to stimulate economic growth and reduce poverty, some authors state that non-agricultural sectors should now receive special attention following the success achieved in some countries in South Asia. These countries have indeed applied a different paradigm: a program of economic growth and poverty reduction based on non-agricultural sectors. This study aims to provide insights into this debate. It draws from the public capital productivity literature to postulate the positive productive externalities of public investment. The results show that, with the same amount of public investment, financed by the same source, public investment in agriculture yields positive impacts that are significantly higher than those yielded by investments in non-agricultural sectors (industry and services). Added value growth in non-agricultural sectors is higher under public investment in agriculture than in non-agricultural sectors.
\end{abstract}

Keywords: poverty, unemployment, public investment, computable general equilibrium

JEL: I32; C68; E24

\section{Introduction}

Burkina Faso is an agriculture-based country. Indeed, more than $80 \%$ of its population depends on this sector for income and employment. Thus, agriculture plays a significant role in the food security of poor households. The grain consumed by Burkinabe households is mostly produced domestically Zidouemba (2014). In the past ten years, Burkina Faso's economic growth has been strong, though erratic, because of numerous exogenous shocks (e.g., poor weather and the world economic crisis). According to the World Bank (2017), the country's growth averaged 5.8\% in real terms between 2001 and 2015. However, because the population has grown rapidly (3.1\% per year), income per capita has increased by only $2.7 \%$ year-on-year.

The results of the survey on households living conditions conducted in 2009 by the National Institute of Statistics and Demography show that the poverty incidence decreased by 2.5\% compared to its level in 2003 (INSD, 2009). In 2009, approximately $44 \%$ of the population still lived below the poverty line, which was estimated at CFA franc 108,454 (USD 185) per capita per year, compared with $46.4 \%$ in $2003^{1}$. Poverty remains predominantly a rural phenomenon: $50.7 \%$ of the population in rural areas lives below the poverty line, compared with $19.9 \%$ of the population in urban areas. Between 2003 and 2009, the incidence of poverty decreased by 1.6\% in rural areas and remained stable in urban areas. The Continuous Multisectoral Survey (CMS) of 2014 indicates a national poverty rate of $40.1 \%$ (INSD, 2015). Thus, the poverty rate has declined over time, but owing to fast population growth this slight decrease translates into an increase in the number of people living in poverty. In short, the level of economic growth achieved and the redistribution mechanism of the benefits of growth were not sufficient to induce a significant reduction in the incidence and severity of poverty in Burkina Faso.

Several authors have noted that the modest decline in the poverty rate is largely due to the difficulties faced by the agricultural sector (Destombes, 2003, Poussart-Vanier, 2006, Smith et al., 2000, Zidouemba, 2014). Burkina Faso's cereal productivity is among the lowest in the world and has been relatively stagnant over the past two decades

\footnotetext{
${ }^{1}$ The poverty line in 2003 was estimated at CFA franc 82,672 (USD 141) per capita per year.
} 
(Tittonell and Giller, 2013). The agricultural sector faces major constraints that weigh on its productivity. Scientific studies on nutrient balance and surveys among peasants support the idea that natural-resource depletion and land degradation are important concerns in this country (Gray, 1999, Lindqvist and Tengberg, 1993, Taonda et al., 1995, Visser et al., 2003). High population growth without additional off-farm job opportunities, combined with low input techniques, translates into growing pressure on the country's natural resources (OECD 2012).

The link between agricultural growth, economic growth and poverty reduction has been widely documented in the economic literature. Traditional economic thought in the first half of the $20^{\text {th }}$ century neglected the central role of the agricultural sector and considered economic growth and development to be a shift in labor from the low-productivity agricultural sector to the high-productivity manufacturing sector (Kuznets, 1955). The factors of production have thus been perceived as more productive in sectors other than agriculture, while the agricultural sector has been seen as relatively unresponsive to economic incentives. Nevertheless, the increasing availability of data from the 1960s helped empirically recognize the central role of agriculture (FAO, 1995). The recognition of the important role of agriculture in economic growth and poverty reduction has emerged as a result of the awareness that agricultural stagnation could be at the root of hunger and the stalling of industrial development.

Singer (1979) was the first to suggest a development strategy based on agriculture. This suggestion has been tested empirically by Adelman (1984), Dowrick and Gemmell (1991) and Vogel (1994). Dowrick and Gemmell (1991) tested how the size of the agricultural sector affects countries' ability to achieve convergent growth, and they found that agricultural productivity for the poorest countries in their sample is converging towards the levels for developed countries. Vogel (1994) is one of the authors who has provided empirical tests based on social accounting matrices (SAM) from 27 developed and developing countries to derive multipliers for agricultural and non-agricultural sectors. Their results confirm strong backward links from agriculture to non-agricultural production, especially at low levels of development. This is generally the case in economies where the agricultural sector contributes significantly to domestic production, export revenues and employment.

Since then, many studies have attempted to investigate the links between agricultural development and economic growth. These studies use different approaches, ranging from cross-country analysis to growth accounting. Using cross-country data, FAO (1995) found an income multiplier of approximately 1.6 for agriculture, implying that one additional unit of agricultural income produces additional income of 0.6 units in non-agricultural sectors. However, the multiplier varies by country depending on the strength of the link between agriculture and other sectors. Self and Grabowski (2007) studied the effects of different direct and indirect measures of agricultural productivity on the rate of economic growth and found a strong correlation between the productivity of the agricultural sector and the growth rate of per capita income. Tiffin and Irz (2006) investigated the causality between the growth of the agricultural sector and economic growth and found a causal direction from the agricultural sector to the aggregate economy, rather than the converse. However, Gollin (2010) underlines that the convergence in agricultural productivity is insufficient to achieve the convergence in income levels. These and other empirical evidence using cross-country data suggest a strong link between the development of the agricultural sector and economic growth.

Alternatively, many scholars have used growth accounting and productivity measurements to investigate the impact of agricultural growth on overall economic growth. Some of these studies argue that, in numerous countries, productivity growth in the agricultural sector has been strong enough to derive the performance of the overall economy. Such evidence has been obtained in both developed (Jorgenson and Gollop, 1992, Mundlak, 2005) and developing (Bosworth and Collins, 2008, Martin and Mitra, 2001) countries. Using time series data from the United States, Jorgenson and Gollop (1992) identified agriculture as the sector with the highest total factor productivity (TFP) growth. Focusing on India and China, Bosworth and Collins (2008) concluded that the agricultural sector has been a major source of economic growth for both of these countries during the past 25 years.

Although we do not intend to provide a full summary of the literature in this regard, it is crucial to briefly present CGEand growth multiplier-based studies; they answer some of the weaknesses of the growth accounting-based studies, such as lack of information on sectoral interdependencies and the causal mechanism (Gollin, 2010). Several single-country (Gebreegziabher et al., 2016, Pauw and Thurlow, 2011), regional (Diao et al., 2010) and global (Zhai et al., 2009) models have been employed to examine the role of change in agricultural productivity on the performance of the wider economy. These studies further provide cleaner causal mechanisms and transmission channels through which the agricultural sector interacts with the rest of the economy.

However, the economic literature is not unanimously favorable to agriculture as the main instrument for eliminating poverty in developing countries. Some studies have questioned the predominant role of agricultural growth in the fight against poverty. For example, Himanshu et al. (2013) argue that for rural India, the non-agricultural sector is the most pro-poor and is therefore the largest contributor to poverty reduction. Collier and Dercon (2014) emphasize that agricultural productivity, especially for smallholder family farming, is so low that poverty reduction in African countries 
will essentially have to come from a radical transformation of agriculture and an exodus from rural areas. Many other authors have emphasized the role of migration in poverty reduction in rural areas (Beegle et al., 2011). However, much of the literature cautioning against the importance of the agricultural sector for poverty reduction does not dispute the effectiveness of agriculture in poverty reduction but rather worries about the cost of the investment required to reach such agricultural growth. It is estimated that these high costs make agricultural investments an inefficient instrument for economic development and poverty reduction (Collier and Dercon, 2014).

In view of these debates in the literature, our objective is to estimate and compare the impacts of public investments in agriculture, industry and services. The aim is to identify the scenario likely to produce the strongest impacts in terms of economic growth, poverty reduction and unemployment in Burkina Faso. To do this, a dynamic Computable General Equilibrium (CGE) model is used because of its ability to take into account agricultural and non-agricultural linkages and to easily represent productivity change (Pauw and Thurlow, 2011). CGE models are also suited for economy-wide impact analysis of exogenous or policy shocks (Hertel, 2002).

The remainder of the paper is organized as follows: after describing the CGE model and data, we present four alternative scenarios simulated with the CGE model (section 2). Section 3 analyzes and discusses the simulation results, while section 4 summarizes findings and policy recommendations.

\section{Material and Method}

The CGE model used for this study is directly adapted from Zidouemba $(2014)^{2}$. It is a recursive dynamic model that works on a yearly time step.

\subsection{General Characteristics}

It is a classical CGE model: (i) consumer maximizes utility subject to an income constraint; (ii) producer maximizes profit subject to a technical constraint defined by production function; (iii) consumers hold fixed factors (capital and labor) so that the remuneration of these factors forms their income; (iv) the quantities of supplied goods are equal to the quantities requested; (v) the market equilibrium is instantaneous and determines the quantities produced and consumed, imports and exports for various goods, and the prices of goods and services and remuneration of production factors; (vi) the government's budget balances expenditures (government consumption and transfers) with revenues from various taxes, as well as transfers from the rest of the world (official development aid); (vii) imperfect substitution between goods produced in different countries (Armington) has been retained.

For the sake of realism, some changes were introduced into the basic CGE model. These changes include labor mobility, unemployment, the dynamics of population and capital accumulation, and externalities derived from public investment.

\subsection{Labor Mobility}

Imperfect labor mobility is modeled to represent the difficulty for the labor force of moving from one major sector to another due to specific job skills and the difficulty of vocational retraining. This is particularly true when considering both the length of time (short-to-medium run) and the situation in developing countries, where public support services for professional retraining are lacking. Three major sectors have been identified: agriculture, industry and services. Labor is then assumed to be perfectly mobile only between sectors belonging to the same major sector (e.g., agricultural labor can move from the rice sector to the corn sector but never to the sector of education). This implies that wages for labor are aggregate sector specific. The assumption of labor mobility is critical in determining the capacity of production sectors to adjust in case of exogenous or policy shocks.

\subsection{Unemployment}

Unemployment is included in the model. Wages are assumed to be rigid, and market equilibrium is achieved by quantity variation, that is to say the number of individuals employed. The initial unemployment rate has been set at $17 \%$ (INSD, 2008). The growth in activity then leads to an increase in the number of workers, which implies a decline in unemployment rather than an increase in wages, as is the case with an assumption of full employment. When all workers are employed, the wage increases to achieve balance in the labor market.

\subsection{Dynamic Recursive}

The dynamics of the model are based on population growth and capital accumulation. The population is expected to grow yearly at an exogenous rate of $3 \%$, corresponding to the current growth rate. This growth has the effect of increasing the labor supply and demand for goods and services. Domestic savings and current account balances determine the level of investment available in the economy for the next period. Investment in each sector (private or public) is a fixed share of total savings and is added to the capital (net depreciation) from previous periods to determine

\footnotetext{
${ }^{2}$ See appendix for the full equations listing.
} 
the capital available to this sector for the next period.

\subsection{Modeling the Impact of Public Capital Externalities}

For public investment in public capital, we adopt the formulation of Estache et al. (2012), where the externality $\left(\Omega_{i, t}\right)$ of public investment depends on the ratio between new investment $\left(I T P_{t}\right)$ and the level of investment in the reference period $\left(I T P_{t 0}\right)$. The production function is then modified as follows:

$$
\begin{gathered}
X D_{i, t}=\Omega_{i, t} \chi_{i}\left(\eta_{i} * C I_{i, t}^{-\phi_{i}}+\left(1-\eta_{i}\right) V A_{i, t}^{-\phi_{i}}\right)^{-1 / \phi_{i}} \\
\Omega_{\mathrm{i}, \mathrm{t}}=\left(\frac{I T P_{t}}{I T P_{t o}}\right)^{\xi_{i}} \\
I T P_{t}=\tau I T_{t}^{P U B}
\end{gathered}
$$

where $X D_{i, t}$ is the volume of production by the sector $i$ at period $t ; C I_{i, t}$ the level of intermediate consumption by sector $i$ at period $t ; V A_{i, t}$ the added value of the sector $i$ at period $t ; \eta_{i}$ et $\phi_{i}$ are parameters of production function; and $\chi_{i}$ is the scale parameter of the production function of the sector $i$ at $t$. The parameter $\tau$ is the share of the total public investment available that the government decides to allocate to infrastructure spending; $\xi_{i}$ is a sector-specific elasticity. The values of this elasticity by activity are derived from Harchaoui and Tarkhani (2003) estimations for the Canadian economy (table 4). Because these values have been estimated for a developed country, and because the economic literature stipulates decreasing returns to public infrastructure, the values could be conservative. Moreover, since the elasticity parameters are less than unity, the returns to public infrastructure are positive, but the growth occurs at a decreasing rate (Estache, Perrault and Savard, 2012).

The public capital stock depreciates at a constant rate, while investment policies increase it. Equation 4 gives the accumulation of capital in the public sector. It is equal to the stock of public capital net of depreciation $\left(\right.$ dep $\left._{p u b}\right)$, plus public investment available after the investment in infrastructure.

$$
A_{k, p u b, t+1}=A_{k, p u b, t}\left(1-d e p_{p u b}\right)+\frac{\theta_{k, p u b}(1-\tau) I T_{t}^{P U B}}{P K_{t}^{P U B}}
$$

where $\theta_{k, p u b}$ is the share of the new capital $k$ in the public sector $p u b ; P K_{t}^{P U B}$ the price of public capital.

\subsection{Data}

To meet our research objective, a social accounting matrix (SAM) for the year 2012 has been developed. The SAM consists of 27 activities, including 15 agricultural activities, producing 58 goods and services, including 16 agricultural products. Production activities use two factors of production (capital and labor) leased to the 60 representative households distinguished by income quintile and regions of residence (12 regions) ${ }^{3}$.

Table 1 gives the structure of the economy of Burkina Faso by activity in 2012 according to the SAM. In terms of GDP, agriculture contributes $36,2 \%$, behind services $(44,3 \%)$ and far ahead of industry $(19,6 \%)$. The agricultural sector's contribution to the value of outputs is estimated at $26,8 \%$, compared with $32,8 \%$ for industry and $40,5 \%$ for services. The share of national labor compensation derived from agriculture is more substantial $(48,8 \%)$ than services $(30,9 \%)$ and industry $(12,3 \%)$. Looking at the share of capital income by sector, only $33 \%$ of the remuneration of capital comes from agriculture. Table 3 shows that export earnings are predominantly made up of primary goods exports (79,5\%). These exports include mainly gold (54\%) and cotton (13,4\%). Imports are mainly made up of industry goods ( $86 \%)$. On average, $36,4 \%$ of agricultural production is exported, far beyond the export share of industry $(3,6 \%)$ and services $(6,2 \%)$. Moreover, the share of imports in domestic absorption is higher for industry $(41,5 \%)$ than for services $(8,1 \%)$ and agriculture $(1,4 \%)$. Table 2 provides the structure of production by activity according to the 2012 SAM. It shows that, on average, the share of labor compensation in added value is higher in agriculture (52\%) than in industry $(28,4 \%)$ and services $(39,2 \%)$. However, the industrial sector uses the most intermediate consumption as a proportion of output $(64,4 \%)$, followed by services $(34,9 \%)$ and agriculture $(19,6 \%)$.

\footnotetext{
${ }^{3}$ There are a total of 13 administrative regions in Burkina Faso (Hauts bassins, Boucle du Mouhoun, Sahel, Est, Sud-Ouest, Centre-Nord, Centre-Ouest, Plateau Central, Nord, Centre-Est, Centre, Cascades, Centre-Sud). However, for this study, the region of Centre and Centre-sud are grouped into one region, the Centre.
} 
Table 1. The structure of the economy of Burkina Faso by activity according to the SAM $2012(\%)$

\begin{tabular}{|c|c|c|c|c|}
\hline & GDP at factor cost & Production & Labor & Capital \\
\hline A_corn & 2.1 & 1.5 & 5.3 & 0.0 \\
\hline A_rice & 1.2 & 0.8 & 3.0 & 0.0 \\
\hline A_millet & 1.6 & 1.3 & 4.0 & 0.1 \\
\hline A_sorghum & 2.6 & 2.0 & 6.6 & 0.1 \\
\hline A_fonio & 0.0 & 0.0 & 0.1 & 0.0 \\
\hline A_tuber & 3.0 & 1.8 & 7.6 & 0.0 \\
\hline A legum & 1.2 & 0.8 & 3.1 & 0.0 \\
\hline A_peanut & 1.2 & 0.9 & 3.2 & 0.0 \\
\hline A_cotton & 3.4 & 4.7 & 7.9 & 0.7 \\
\hline A_oleaginous & 2.0 & 1.2 & 5.0 & 0.1 \\
\hline A_horticulture & 0.8 & 0.5 & 2.0 & 0.0 \\
\hline A_fruits & 1.0 & 0.6 & 0.5 & 1.6 \\
\hline A_breeding & 12.1 & 8.1 & 0.1 & 23.0 \\
\hline A_forfishhunt & 3.9 & 2.5 & 0.3 & 7.3 \\
\hline A_extraction & 8.7 & 9.9 & 4.9 & 10.4 \\
\hline A_meat & 0.2 & 3.0 & 0.3 & 0.2 \\
\hline A_cannedfish & 0.1 & 0.1 & 0.0 & 0.1 \\
\hline A_cannedfruits & 0.2 & 0.4 & 0.0 & 0.3 \\
\hline A_dietaryfat & 0.3 & 0.7 & 0.1 & 0.4 \\
\hline A_grains & 0.4 & 0.8 & 0.2 & 0.5 \\
\hline A_othfoodprod & 1.4 & 4.5 & 1.3 & 1.2 \\
\hline A_tabacco & 0.4 & 0.5 & 0.5 & 0.3 \\
\hline A textileleather & 0.1 & 0.6 & 0.1 & 0.1 \\
\hline A othind & 7.8 & 12.2 & 4.9 & 9.3 \\
\hline A_trade & 9.3 & 9.2 & 2.0 & 11.9 \\
\hline A privservices & 15.4 & 15.8 & 8.5 & 18.7 \\
\hline A pubservices & 19.6 & 15.4 & 28.4 & 13.6 \\
\hline Total agriculture & 36.2 & 26.8 & 48.8 & 33.0 \\
\hline Total Industry & 19.6 & 32.8 & 12.3 & 22.7 \\
\hline Total services & 44.3 & 40.5 & 38.9 & 44.3 \\
\hline Total & 100.0 & 100.0 & 100.0 & 100.0 \\
\hline
\end{tabular}

Table 2. The structure of production by activity according to the SAM $2012(\%)$

\begin{tabular}{lccc}
\hline & \multicolumn{2}{c}{$\%$ of Added Value } & \multirow{2}{*}{ Inputs (\% of production) } \\
\hline A_corn & 98.8 & Capital & 18.4 \\
A_rice & 98.6 & 1.2 & 8.3 \\
A_millet & 97.9 & 1.4 & 28.6 \\
A_sorghum & 98.2 & 2.1 & 22.1 \\
A_fonio & 98.3 & 1.8 & 21.0 \\
A_tuber & 99.6 & 1.7 & 1.5 \\
A_legum & 99.9 & 0.4 & 4.3 \\
A_peanut & 98.2 & 0.1 & 19.0 \\
A_cotton & 89.6 & 1.8 & 56.9 \\
A_oleaginous & 97.4 & 10.4 & 0.5 \\
A_horticulture & 97.6 & 2.6 & 9.2 \\
A_fruits & 17.6 & 2.4 & 0.1 \\
A_breeding & 0.2 & 82.4 & 11.3 \\
A_forfishhunt & 2.9 & 99.8 & 6.7 \\
A_extraction & 25.8 & 97.1 & 47.8 \\
A_meat & 53.2 & 74.2 & 95.3 \\
A_cannedfish & 0.0 & 46.8 & 55.6 \\
A_cannedfruits & 4.5 & 100.0 & 71.0 \\
A_dietaryfat & 21.2 & 95.5 & 75.2 \\
A_grains & 21.7 & 78.8 & 68.9 \\
A_othfoodprod & 44.5 & 78.3 & 81.1 \\
A_tabacco & 57.1 & 55.5 & 58.9 \\
A_textileleather & 48.5 & 42.9 & 92.7 \\
A_othind & 27.7 & 51.5 & 62.0 \\
A_trade & 10.7 & 72.3 & 40.4 \\
A_privservices & 25.1 & 89.3 & 42.2 \\
A_pubservices & 60.5 & 74.9 & 24.2 \\
\hline Agriculture & 52.0 & 39.5 & 19.6 \\
Industry & 28.4 & 48.0 & 34.9 \\
Services & 39.2 & 71.6 & \\
\hline & & 60.8 & \multirow{2}{*}{. } \\
\hline
\end{tabular}


Table 3. The structure of the Burkina Faso economy by product according to the SAM 2012 (\%)

\begin{tabular}{|c|c|c|c|c|c|}
\hline & Exports & Imports & Absorption & Exports (\% of production) & Imports ( $\%$ of absorption) \\
\hline P_corn & 0.5 & 0.0 & 1.2 & 5.3 & 0.1 \\
\hline $\mathrm{P}$ rice & 0.0 & 0.0 & 0.6 & 0.8 & 1.4 \\
\hline $\mathrm{P}_{-}^{-}$millet & 0.0 & 0.0 & 1.1 & 0.2 & 0.6 \\
\hline P_sorghum & 0.1 & & 1.7 & 0.4 & \\
\hline $\mathrm{P}^{-}$fonio & 0.0 & 0.0 & 0.1 & 7.6 & 0.5 \\
\hline $\mathrm{P}^{-}$tuber & 0.2 & 0.1 & 1.5 & 1.8 & 1.0 \\
\hline $\mathrm{P}^{-}$legum & 0.2 & 0.0 & 0.6 & 5.3 & 0.1 \\
\hline P_peanut & 1.2 & & 0.6 & 21.0 & \\
\hline $\mathrm{P}$ _cotton & 13.4 & 0.0 & 2.2 & 46.3 & 0.1 \\
\hline $\mathrm{P}$ _oleaginous & 5.7 & 0.1 & 0.2 & 79.3 & 4.9 \\
\hline $\mathrm{P}$ horticulture & 0.1 & 0.2 & 0.4 & 4.2 & 11.0 \\
\hline $\mathrm{P}^{-}$fruits & 1.3 & 0.6 & 0.5 & 34.4 & 27.1 \\
\hline P_breeding & 2.0 & 0.0 & 7.0 & 3.9 & 0.1 \\
\hline $\mathrm{P}_{-}$forfishhunt & 0.0 & 0.0 & 2.2 & 0.3 & 0.1 \\
\hline $\mathrm{P}^{-}$gold & 54.0 & 0.0 & 0.1 & 99.8 & 0.1 \\
\hline P_othextraction & 0.8 & 0.3 & 0.2 & 46.5 & 27.4 \\
\hline P_meat & 0.0 & 0.0 & 2.7 & 0.0 & 0.1 \\
\hline $\mathrm{P}^{-}$cannedfish & 0.0 & 0.7 & 0.3 & 2.9 & 51.4 \\
\hline $\mathrm{P}$ cannedfruits & 0.1 & 0.3 & 0.2 & 6.0 & 31.1 \\
\hline $\mathrm{P}^{-}$juice & 0.1 & 0.2 & 0.3 & 5.1 & 14.6 \\
\hline $\mathrm{P}$ _cookingoil & 0.3 & 0.6 & 0.3 & 20.9 & 41.7 \\
\hline P_Sheabutter & 0.2 & & 0.2 & 16.3 & \\
\hline $\mathrm{P}^{-}$peanutpaste & 0.0 & 0.0 & 0.1 & 0.0 & 0.0 \\
\hline $\mathrm{P}$ peanutcake & & & 0.1 & & \\
\hline P_othdietaryfat & & 0.2 & 0.1 & & 91.0 \\
\hline $\mathrm{P}$ huskedrice & 0.0 & 2.0 & 0.7 & 1.7 & 58.8 \\
\hline $\mathrm{P}$ wheatflour & & 0.4 & 0.3 & & 31.8 \\
\hline P_othecerflour & 0.0 & 0.1 & 0.3 & 0.3 & 8.9 \\
\hline P_othflour & & 0.0 & 0.0 & & 100.0 \\
\hline P bran\&residues & 0.0 & 0.0 & 0.0 & 76.4 & 19.0 \\
\hline P starchproducts & 0.0 & 0.1 & 0.1 & 0.1 & 17.1 \\
\hline $\mathrm{P}$ _animalfeed & & 0.0 & 0.0 & & 100.0 \\
\hline $\mathrm{P}^{-}$bread & & 0.1 & 1.1 & & 1.7 \\
\hline $\mathrm{P}_{-}^{-}$biscuit & & 0.1 & 0.0 & & 100.0 \\
\hline $\mathrm{P}^{-}$pasta & 0.0 & 0.2 & 0.1 & 7.9 & 67.4 \\
\hline $\mathrm{P}$ sugar & 0.0 & 0.8 & 0.4 & 0.5 & 41.2 \\
\hline $\mathrm{P}_{-}^{-}$chocolate & & 0.1 & 0.0 & & 26.7 \\
\hline P_coffee & & 0.7 & 0.1 & & 100.0 \\
\hline $\mathrm{P}^{-}$dairy products & 0.0 & 0.5 & 0.4 & 0.3 & 31.6 \\
\hline P_soumbala & 0.0 & 0.0 & 0.3 & 1.9 & 1.9 \\
\hline P_othcondiments & 0.0 & 0.7 & 0.2 & 0.5 & 74.3 \\
\hline P_dolo & & 0.0 & 2.0 & & 0.1 \\
\hline $\mathrm{P}$ othbeer & 0.0 & 0.3 & 0.6 & 0.0 & 11.0 \\
\hline P_othalcoholicbeverages & 0.0 & 0.1 & 0.0 & 100.0 & 93.0 \\
\hline P_softdrink & 0.0 & 0.1 & 0.1 & 0.5 & 43.8 \\
\hline P_mineralwater & 0.0 & 0.0 & 0.0 & 27.6 & 22.5 \\
\hline P_cigarette & 0.1 & 0.1 & 0.6 & 4.6 & 4.2 \\
\hline P_othtobacco & & 1.5 & 0.4 & & 70.8 \\
\hline $\mathrm{P}_{-}^{-}$tissues & 0.4 & 0.0 & 0.5 & 16.0 & 2.2 \\
\hline P_othtext & & 1.0 & 0.2 & & 86.0 \\
\hline $\mathrm{P}$ clothing & 0.0 & 0.7 & 0.3 & 6.8 & 46.3 \\
\hline $\mathrm{P}$ leather & 0.2 & 0.0 & 0.1 & 39.6 & 0.1 \\
\hline P_travelarticle & & 0.1 & 0.0 & & 100.0 \\
\hline $\mathrm{P}$ footwear & 0.0 & 0.2 & 0.1 & 29.2 & 55.3 \\
\hline P_othind & 3.6 & 73.9 & 33.2 & 4.6 & 47.1 \\
\hline $\mathrm{P}_{-}$trade & & & 7.2 & & \\
\hline $\mathrm{P}$ _privservices & 14.1 & 9.3 & 13.4 & 14.5 & 14.7 \\
\hline P pubservices & 1.3 & 3.3 & 12.6 & 1.4 & 5.6 \\
\hline Total agriculture & 79.5 & 1.3 & 20.2 & 36.4 & 1.4 \\
\hline Total Industry & 5.1 & 86.0 & 46.5 & 3.6 & 41.5 \\
\hline Total services & 15.4 & 12.7 & 33.2 & 6.2 & 8.1 \\
\hline Total & 100.0 & 100.0 & 100.0 & 16.5 & 21.7 \\
\hline
\end{tabular}

\subsection{Simulations}

For our analysis, we alternately perform an increase in public capital in agriculture, industry and services. However, the nature of public capital is not specified in this research. Public capital can be considered as the set of public goods and 
services that are involved in the production process as complementary inputs to other factors of production (capital, labor, etc.). They contribute to an increase in returns to private investment through the reduction of production costs. Public capital can take the form of rural roads, irrigation, storage infrastructure for the agricultural sector, energy infrastructure for industry and telecommunications infrastructure for services. The idea is to simulate an annual investment in public capital amounting to $25 \%$ of the amount of public investment available. This means that the financing of these investments comes from a reduction in public investment in the public sector. More specifically, in the baseline scenario, there is no investment in public capital to increase the productivity of private sectors. Thus, the parameter $\tau$ is set to 0 , and the externality variable $\Omega_{i, t}$ is exogenous and assigned the value 1 . In the three alternative scenarios, the parameter $\tau$ is assigned the value of 0,25 , while the variable $\Omega_{i, t}$ is endogenous, and its value represents the level of externality of public capital. This externality differs by sector according to an elasticity that is sector-specific. The simulations are run over a period of 10 years, 2012 being the reference year. It is important to reiterate that the main objective of the paper is to verify the importance of the difference of impacts - in terms of poverty and unemployment - of public investment according to the aggregate sector in which that investment is undertaken. Considering that public investments are fully supported by the government allows us to remain within the logic of realism. One can imagine that part or all these investments are supported by official development assistance. The financing can also come from a greater tax mobilization to raise the tax burden from $17 \%$ today to $20 \%$, according to the standards of the West African Economic and Monetary Union (WAEMU).

Table 4. Exogenous parameters

\begin{tabular}{|c|c|c|c|}
\hline & \multirow{2}{*}{$\begin{array}{l}\text { Elasticity of public } \\
\text { capital }\left(\xi_{i}\right)\end{array}$} & \multicolumn{2}{|c|}{ CES exponent parameters } \\
\hline & & Production $\left(\phi_{i}\right)$ & Added value $\left(\mu_{i}\right)$ \\
\hline A_corn & 0.05153 & 0.3 & 0.7 \\
\hline A_rice & 0.05153 & 0.3 & 0.7 \\
\hline A_millet & 0.05153 & 0.3 & 0.7 \\
\hline A_sorghum & 0.05153 & 0.3 & 0.7 \\
\hline A_fonio & 0.05153 & 0.3 & 0.7 \\
\hline A_tuber & 0.05153 & 0.3 & 0.7 \\
\hline A_legum & 0.05153 & 0.3 & 0.7 \\
\hline A_peanut & 0.05153 & 0.3 & 0.7 \\
\hline A_cotton & 0.05153 & 0.3 & 0.7 \\
\hline A_oleaginous & 0.05153 & 0.3 & 0.7 \\
\hline A_horticulture & 0.05153 & 0.3 & 0.7 \\
\hline A_fruits & 0.05153 & 0.3 & 0.7 \\
\hline A_breeding & 0.05153 & 0.3 & 0.7 \\
\hline A_forfishhunt & 0.01438 & 0.3 & 0.7 \\
\hline A_extraction & 0.02648 & 0.3 & 0.7 \\
\hline A_meat & 0.03813 & 0.3 & 0.7 \\
\hline A_cannedfish & 0.03813 & 0.3 & 0.7 \\
\hline A_cannedfruits & 0.03813 & 0.3 & 0.7 \\
\hline A_dietaryfat & 0.03813 & 0.3 & 0.7 \\
\hline A_grains & 0.03813 & 0.3 & 0.7 \\
\hline A_othfoodprod & 0.03813 & 0.3 & 0.7 \\
\hline A_tabacco & 0.01871 & 0.3 & 0.7 \\
\hline A_textileleather & 0.02058 & 0.3 & 0.7 \\
\hline A_othind & 0.00205 & 0.3 & 0.7 \\
\hline A_trade & 0.12896 & 0.3 & 0.7 \\
\hline A_privservices & 0.07529 & 0.3 & 0.7 \\
\hline A_pubservices & 0.06216 & 0.3 & 0.7 \\
\hline
\end{tabular}

Elasticity of public capital $\left(\xi_{-}\right.$i) are derived from Harchaoui and Tarkhani (2003); CES elasticities in the production function are derived from Zidouemba (2014).

In the baseline scenario, annual GDP growth is $6.1 \%$. This is comparable in size to the growth observed over the previous decade. The three aggregate sectors (agriculture, industry and service) experienced annual growth rates of $6,2 \%, 5,7 \%$ and $6,1 \%$, respectively (table 5 ). A question of interest is whether the poorest households are able to achieve or exceed the 2012 poverty line estimated at CFA franc 130,735 per person per year (INSD, 2012). Figure 1 shows the evolution of per capita income in that scenario for the poorest households (the first quintile, or the poorest $20 \%$ of the population in each region) in the twelve regions of Burkina Faso. Progress is far too slow, as only three regions of the twelve cross the poverty line by the end of the simulation period, 2022. These regions are the Sud-Ouest, the Plateau central and the Centre-Est. Thus, although the 6\% economic growth recently observed can be described as strong, it is still insufficient to hope for an escape from poverty because of the strong growth of the population. Strong population 
growth also explains the small decline in the unemployment rate from $17 \%$ to $13 \%$. In absolute terms, this implies an increase in the number of unemployed persons from 2.6 million in 2012 to 2.8 million in $2022^{4}$. The main lesson that can be drawn from this scenario is that the apparent macroeconomic performance observed in Burkina Faso is only an illusion. It does not allow the poorest of the population to get out of their precarious situation; on the contrary, the number of unemployed persons increases over time. As is frequently observed, this situation can be an ingredient of social tension.

In the scenario of exclusive public investment in agriculture, progress is clear. Economic growth rises from $6.1 \%$ to $10.4 \%$ per year. Agriculture experiences the highest growth in added value (11\% per year). Growth in non-agricultural sectors is not far behind. It is as strong in the industry sector (10.5\% per year) as in the services sector (9.6\% per year). The momentum generated by the agricultural sector is reflected in all sectors of the economy because of large spillover effects. The strong economic growth results in a significant drop in the unemployment rate, from $17 \%$ to $3.5 \%$ by 2022 . This corresponds to a reduction in the number of unemployed persons from 2,696,409 in 2012 to 712,958 in 2022, based on job creation of 200,000 per year (table 5). The per capita income analysis (figure 2) shows that, except for the Centre region, the poorest households in all regions reach the poverty line over the 10 years of the simulation.

If public investment is made in the industrial sector, the economy grows slightly more strongly than in the baseline scenario (7.4\%, compared to $6.1 \%$ in the baseline). The growth in added value for the three aggregate sectors is $7.3 \%$ per year for agriculture and industry and $7.7 \%$ for services. The unemployment rate reaches $10 \%$ by 2022 . Annual job creation is thus estimated at 70,000 (table 5). In terms of per capita income growth, it appears that the poorest households in three regions are unable to escape from poverty by 2022 (figure 3). These regions are Hauts bassins, the Sahel, and the Centre. It is worth noting that public investment in agriculture generates higher added value for the industrial and service sectors than direct investment in these sectors. This means that in the current context of Burkina Faso, the indirect impact of an "agricultural revolution" on non-agricultural sectors is more important than an "industrial revolution." This result confirms the leading role of agriculture in the Burkina Faso economy.

Investment in the services sector also provides interesting outcomes. When public capital is increased in this sector, real GDP growth increases from $6.1 \%$ to $7.4 \%$ per year. This growth is mainly driven by the tertiary sector, whose annual growth is $7.8 \%$, compared to $6.1 \%$ in the baseline. Agriculture and industry grow by $7.1 \%$ and $7.3 \%$, respectively. The unemployment rate is estimated at $6 \%$, which corresponds to job creation of about 150,000 jobs per year (table 5). Although the impact of investment in that aggregate sector on real GDP growth is like that obtained via the public investment in industry, it should be stressed that the positive effect on employment in this scenario is higher than with investment in industry. This is attributable to the fact that the services sector is more labor intensive than the industry sector. The poorest households in five regions are unable to reach the poverty line by 2022 (figure 4). Thus, even if the public investment in the secondary and tertiary sectors gives the same rate of economic growth, investment in the industrial sector is more effective in terms of poverty reduction. This result is explained by the fact that agricultural growth is stronger under investment in industry (7.3\%) than in services $(7.1 \%)$.

It is clear from these simulations that, for the same amount invested in agriculture or in the industrial or services sectors, investment in agriculture produces better results in terms of economic growth, job creation and income generation (figure 5 and table 5). The structure of Burkina Faso's economy as presented in section 2.2 makes it easy to understand the results of these simulations. Agriculture accounts for more than one third of national GDP (36.2\%). Nearly half of workers' remuneration comes from agriculture (49\%). The development of this sector also means a significant increase in export earnings because approximately $80 \%$ of export earnings come from agricultural goods. Unlike non-agricultural goods, agricultural goods are mostly intended for export. Indeed, $36 \%$ of agricultural production is exported, versus $4 \%$ and $6 \%$ respectively for the industrial and service sectors. In terms of imports, agricultural goods have the smallest contribution to the current account deficit, given that imports of agricultural products account for only $1.4 \%$ of the domestic absorption of agricultural goods, versus $41,5 \%$ and $8,1 \%$ for the industrial and service sectors, respectively. The share of labor compensation in added value is higher in agriculture than in non-agricultural sectors. Since the marginal propensity of the rural poor to consume is generally higher than that of the urban population, and their consumption is more concerned with domestic production, the impact of higher farm income on the economy is greater than the increase in non-farm income. Finally, non-agricultural sectors are more intensive in intermediate consumption than the agricultural sector. For many of these sectors, such as agroindustry and restoration services, the bulk of intermediate consumption consists of agricultural goods. Thus, the increase in agricultural production, which implies a decrease in the prices of agricultural products, is favorable to non-agricultural sectors, as this implies a significant reduction in production costs. The reduction in production costs may be more favorable to non-agricultural

\footnotetext{
${ }^{4}$ According to the Integral Survey on the Living Conditions of Households (EICVM) conducted in 2009, $91.8 \%$ of the Burkinabe population is considered as active population.
} 
sectors than direct investment in these sectors. This is what we see in our simulations, where the scenario of investment in agriculture is more profitable to industry and services than the scenario of the investment in these sectors themselves. All these characteristics combine to explain the robustness of economic growth in the scenario of public investment in agriculture.

These results confirm the idea that Burkina Faso's authorities would benefit from focusing the fight against poverty and unemployment on agriculture. However, the results obviously do not invite them to move completely from non-agricultural sectors to the agricultural sector. Indeed, more favorable results could be achieved by simultaneously investing in the three aggregate sectors when mobilization of internal resources can be complemented by external resources in the framework of partnerships with countries and institutions providing official development assistance.

Table 5. Summary of macroeconomic impacts

\begin{tabular}{|c|c|c|c|c|c|c|}
\hline & $\begin{array}{c}\text { Annual } \\
\text { GDP } \\
\text { growth }(\%)\end{array}$ & $\begin{array}{l}\text { Agricultural } \\
\text { annual GDP } \\
\text { growth (\%) }\end{array}$ & $\begin{array}{c}\text { Industry } \\
\text { annual GDP } \\
\text { growth (\%) }\end{array}$ & $\begin{array}{c}\text { Services } \\
\text { annual GDP } \\
\text { growth }(\%)\end{array}$ & $\begin{array}{l}\text { Unemployment } \\
\text { rate }(\%)\end{array}$ & $\begin{array}{l}\text { Number of } \\
\text { job creation }\end{array}$ \\
\hline Baseline & 6.1 & 6.2 & 5.7 & 6.1 & 13 & $+0^{*}$ \\
\hline Investment in agriculture & 10.4 & 11 & 10.5 & 9.6 & 3.5 & 200000 \\
\hline Investment in industry & 7.4 & 7.3 & 7.3 & 7.7 & 10 & 70000 \\
\hline Investment in services & 7.4 & 7.1 & 7.3 & 7.8 & 6 & 150000 \\
\hline
\end{tabular}

* Due to the strong population growth, GDP growth of $6 \%$ per year allows a drop in the unemployment rate but seems insufficient to induce a decrease in the number of unemployed.

Source: CGE model simulations

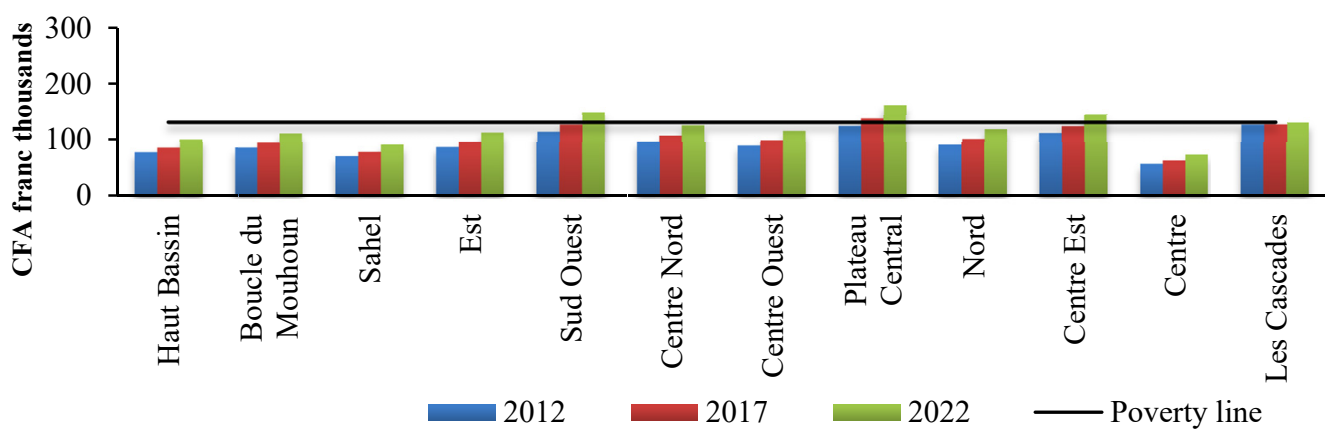

Figure 1. Income Per capita of the first quintile (the poorest households) in the baseline

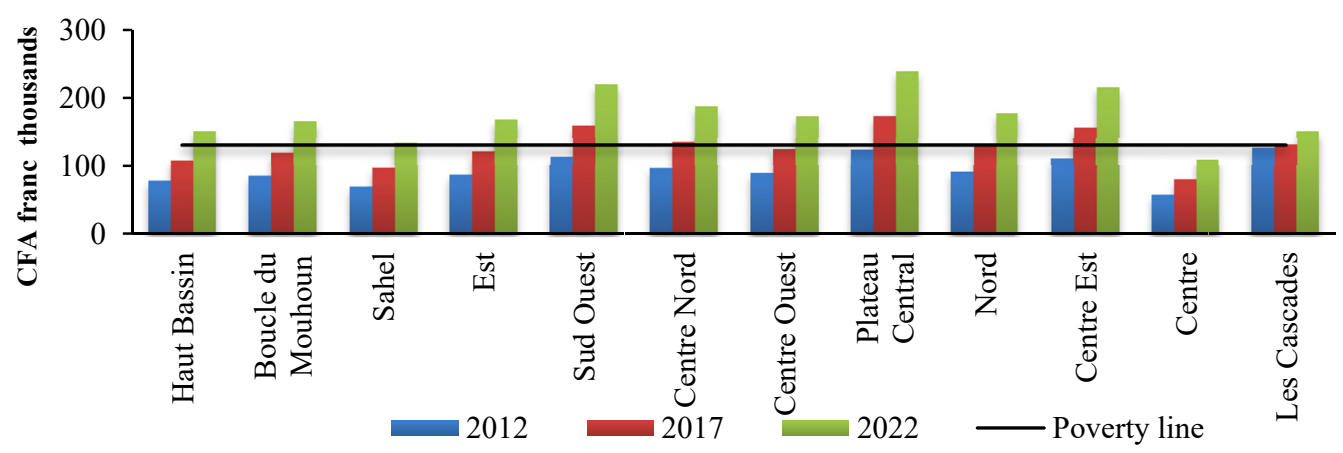

Figure 2. Income Per capita of the first quintile (the poorest households) in public investment in agriculture

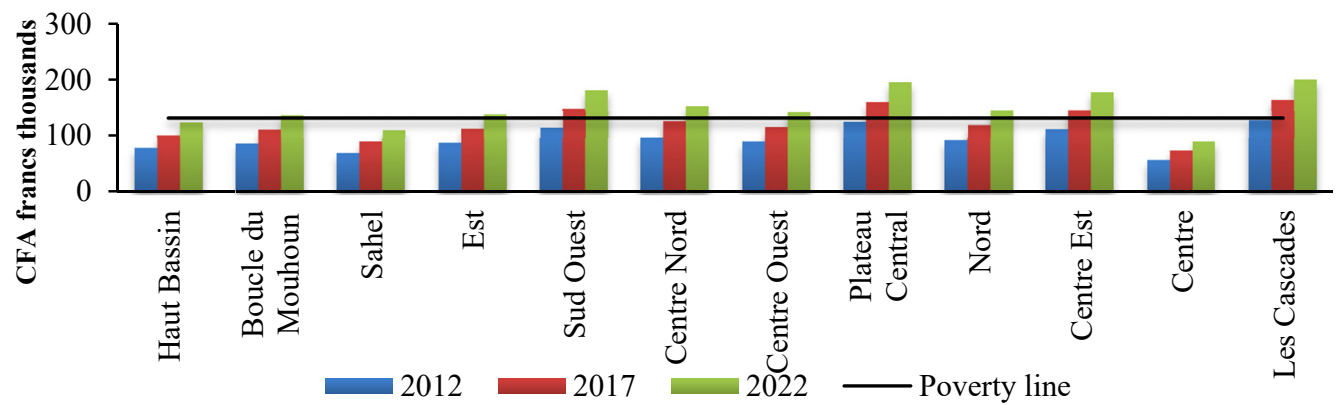

Figure 3. Income Per capita of the first quintile (the poorest households) in public investment in industry 


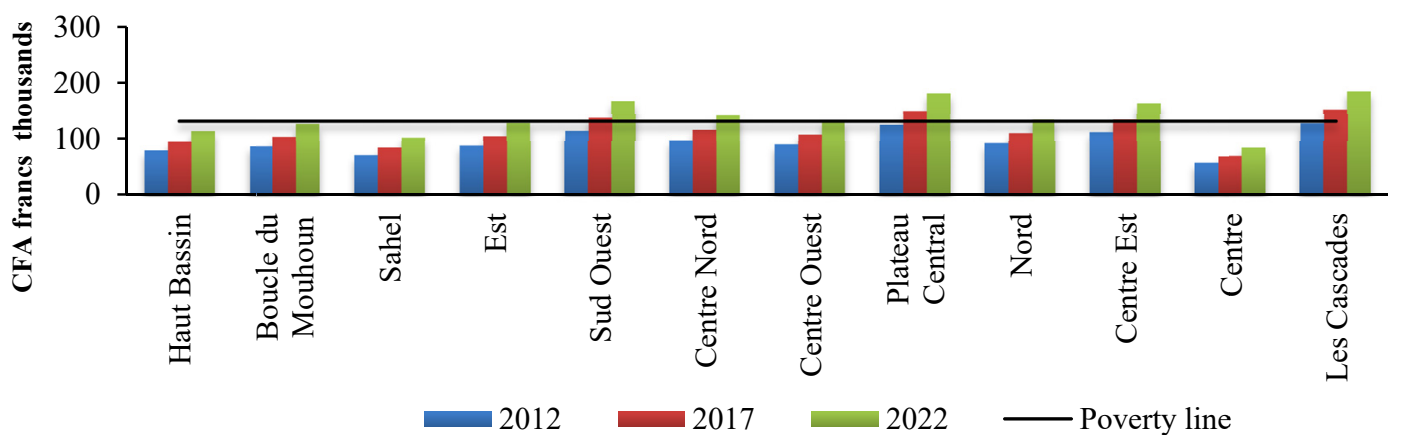

Figure 4. Income Per capita of the first quintile (the poorest households) in public investment in services

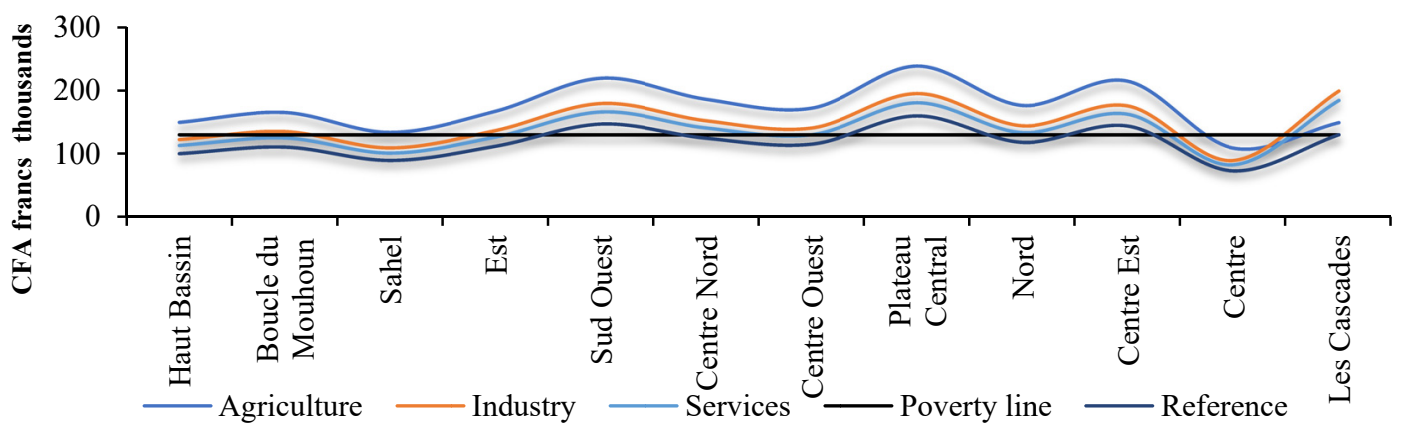

Figure 5. Income Per capita of the first quintile (the poorest households) at the end of the simulation period (2022)

\section{Conclusion}

The modeling exercise has allowed us to analyze the impact of scaling up public capital in the private sector in Burkina Faso. We examine and compare alternative sources of economic growth by classifying the economy into three aggregate sectors (agriculture, industry and services). We observe from the analysis that, compared to non-agricultural sectors, an increase in public investment in the agricultural sector could result in a proportional gain in agricultural added value, with noticeable economy-wide implications. This scenario is more profitable to non-agricultural sectors than the scenarios of public investment in non-agricultural sectors. This further suggests that, in line with the literature on the determining role of agriculture, the agricultural sector should be afforded a high priority in the government's investment plan. Hence, we were able to identify the sector on which to focus public policy and government finance. The economic structure has contributed to producing diversified results for the same amount of investment funded by the same source with the same model. The structure of the economy where investment policy is applied then needs to be considered.

Obviously, the results discussed here are obtained from a stylized model that does not pretend to represent all the complex relationships of Burkina Faso's economy and diversity. For example, the use of a constant rate for population growth is a potential limitation, as this rate is likely to vary significantly from one year to another ${ }^{5}$. Moreover, the perfect mobility assumption of labor within the agricultural sector may be rather strong, thus leading to overestimated impacts. Movements of workers across agricultural sectors can indeed be hampered by high non-linear transaction costs that are not integrated into the model.

Moreover, although the disaggregation of households is already very detailed (60 types of households distinguished according to the region of residence and the income quintile), a representative household approach does not allow for the variability either inside the type of household or between individuals within the same household to be considered. A micro-simulation approach would allow for a more detailed analysis of the impacts on individuals.

Finally, the issue of the feasibility of public investment policy and its effectiveness in improving the productivity of private sectors is critical but not addressed in this paper, thus justifying a separate study. It is clear that difficulties are numerous, as public investment requires well-functioning institutions to be effective.

\section{References}

Adelman, I. (1984). Beyond export-led growth. World Development, 12(9), 937-949. https://doi.org/10.1016/0305-750X(84)90050-0

Beegle, K., Weerdt, J. D., \& Dercon, S. (2011). Migration and Economic Mobility in Tanzania: Evidence from a Tracking Survey. The Review of Economics and Statistics, 93(3), 1010-1033.

\footnotetext{
${ }^{5}$ See, for example, the evolution of the national rate over a long period: http://data.worldbank.org/indicator/SP.POP.GROW?locations=BF
} 
https://doi.org/10.1162/REST_a_00105

Bosworth, B., \& Collins, S. M. (2008). Accounting for growth: comparing China and India. The Journal of economic perspectives, 22(1), 45-66. https://doi.org/10.1257/jep.22.1.45

Collier, P., \& Dercon, S. (2014). African Agriculture in 50 Years: Smallholders in a Rapidly Changing World? World Development, 63, 92-101. doi:https://doi.org/10.1016/j.worlddev.2013.10.001

Destombes, J. (2003). Les causes structurelles de l'insécurité alimentaire chronique en Afrique. Études de cas: Éthiopie, Burkina Faso et Zambie Retrieved from http://www.hubrural.org/IMG/pdf/causes_insecurite_alimentaire_resume.pdf

Diao, X., Hazell, P., \& Thurlow, J. (2010). The Role of Agriculture in African Development. World Development, 38(10), 1375-1383. https://doi.org/10.1016/j.worlddev.2009.06.011

Dowrick, S., \& Gemmell, N. (1991). Industrialisation, Catching Up and Economic Growth: A Comparative Study Across the World's Capitalist Economies. The Economic Journal, 101(405), 263-275. https://doi.org/10.2307/2233817

Estache, A., Perrault, J. F., \& Savard, L. (2012). The Impact of Infrastructure Spending in Sub-Saharan Africa: A CGE Modeling Approach. Economics Research International, 2012, 1-18. https://doi.org/10.1155/2012/875287

FAO. (1995). World agriculture: towards 2010. Chichester, UK: Wiley.

Gebreegziabher, Z., Stage, J., Mekonnen, A., \& Alemu, A. (2016). Climate change and the Ethiopian economy: a CGE analysis. Environment and Development Economics, 21(2), 205-225. https://doi.org/10.1017/S1355770X15000170

Gollin, D. (2010). Chapter 73 Agricultural Productivity and Economic Growth. Handbook of Agricultural Economics, 4, 3825-3866. https://doi.org/10.1016/S1574-0072(09)04073-0

Gray, L. C. (1999). Is land being degraded? A multi-scale investigation of landscape change in southwestern Burkina Faso. Land Degradation \& Development, $10(4), \quad 329-343$. https://doi.org/10.1002/(SICI)1099-145X(199907/08)10:4<329::AID-LDR361>3.0.CO;2-I

Harchaoui, T. M., \& Tarkhani, F. (2003). Le capital public et sa contribution à la productivité du secteur des entreprises du Canada. Retrieved from Ottawa: http://publications.gc.ca/site/eng/9.591519/publication.html

Hertel, T. W. (2002). Chapter 26 Applied general equilibrium analysis of agricultural and resource policies. In L. G. Bruce \& C. R. Gordon (Eds.), Handbook of Agricultural Economics (Vol. Volume 2, Part A, pp. 1373-1419): Elsevier.

Himanshu, L. P., Murgai, R., \& Stern, N. (2013). Nonfarm diversification, poverty, economic mobility, and income inequality: a case study in village India. Agricultural Economics, 44(4-5), 461-473. https://doi.org/10.1111/agec.12029

INSD. (2008). Tableau de bord social du Burkina Faso. Retrieved from Ouagadougou:

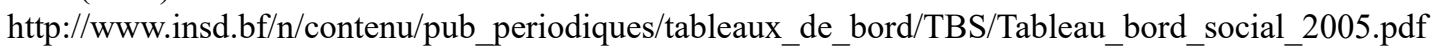

INSD. (2009). Analyse de quelques résultats des données de la phase principale de l'Enquête Intégrale sur les Conditions de Vie des Ménages (EICVM) 2009. Retrieved from Ouagadougou: http://www.insd.bf/n/nada/index.php/catalog/15

INSD. (2012). Annuaire $\quad$ statistique $2012 . \quad$ Retrieved from http://www.insd.bf/n/contenu/pub_periodiques/annuaires_stat/Annuaires_stat_nationaux_BF/Annuaire_stat_2012. pdf

INSD. (2015). Profil de pauvreté et d'inégalités Résultats de l'enquête multisectorielle continue (EMC) - phase 1: Institut National des Statistiques et de la Démographie.

Jorgenson, D. W., \& Gollop, F. M. (1992). Productivity Growth in U.S. Agriculture: A Postwar Perspective. American Journal of Agricultural Economics, 74(3), 745-750. https://doi.org/10.2307/1242588

Kuznets, S. (1955). Economic growth and income inequality. The American economic review, 1-28.

Lindqvist, S., \& Tengberg, A. (1993). New evidence of desertification from case studies in Northern Burkina Faso. $\begin{array}{llllll}\text { Geografiska Annaler. Series A. Physical } & \text { Geography, } & 75, & 135 .\end{array}$ https://doi.org/10.1080/04353676.1993.11880390

Martin, W., \& Mitra, D. (2001). Productivity Growth and Convergence in Agriculture versus Manufacturing. Economic Development and Cultural Change, 49(2), 403-422. https://doi.org/10.1086/452509

Mundlak, Y. (2005). Economic Growth: Lessons from Two Centuries of American Agriculture. Journal of Economic 
Literature, 43(4), 989-1024. https://doi.org/10.1257/002205105775362005

OECD. (2012). Cadre d'action pour l'investissement agricole au Burkina Faso. Retrieved from Ouagadougou: https://doi.org/10.1787/9789264169098-fr

Pauw, K., \& Thurlow, J. (2011). Agricultural growth, poverty, and nutrition in Tanzania. Food Policy, 36(6), 795-804. https://doi.org/10.1016/j.foodpol.2011.09.002

Poussart, V. M. (2006). Jeux d'acteurs dans le système alimentaire burkinabé: normes, conflits et compromis dans le marché céréalier et la gestion de l'aide alimentaire d'urgence. (PhD), Paris 1 (IEDES), Paris. Retrieved from $\mathrm{http} / /$ horizon.documentation.ird.fr/exl-doc/pleins_textes/divers13-07/010041087.pdf

Self, S., \& Grabowski, R. (2007). Economic development and the role of agricultural technology. Agricultural Economics, 36(3), 395-404. https://doi.org/10.1111/j.1574-0862.2007.00215.x

Singer, H. W. (1979). Policy implications of the Lima target. Industry and development, 3, 17-32.

Smith, L. C., El Obeid, A. E., \& Jensen, H. H. (2000). The geography and causes of food insecurity in developing countries. Agricultural Economics, 22(2), 199-215. https://doi.org/10.1111/j.1574-0862.2000.tb00018.x

Taonda, J. B. S., Bertrand, R., Dickey, J., Morel, J. L., \& Sanon, K. (1995). Dégradation des sols en agriculture minière au Burkina Faso. Cahiers Agricultures, 4(5), 363-368.

Tiffin, R., \& Irz, X. (2006). Is agriculture the engine of growth? Agricultural Economics, 35(1), 79-89. https://doi.org/10.1111/j.1574-0862.2006.00141.x

Tittonell, P., \& Giller, K. E. (2013). When yield gaps are poverty traps: The paradigm of ecological intensification in African smallholder agriculture. Field Crops Research, 143, 76-90. https://doi.org/10.1016/j.fcr.2012.10.007

Visser, S. M., Leenders, J. K., \& Leeuwis, M. (2003). Farmers' perceptions of erosion by wind and water in northern Burkina Faso. Land Degradation and Development, 14(1), 123-132. https://doi.org/10.1002/ldr.530

Vogel, S. J. (1994). Structural changes in agriculture: production linkages and agricultural demand-led industrialization. Oxford Economic Papers, 46(1), 136-156. https://doi.org/10.1093/oxfordjournals.oep.a042116

World Bank. (2017). World Development Indicators (WDI). Retrieved from http://data.worldbank.org/data-catalog/world-development-indicators

Zhai, F., Lin, T., \& Byambadorj, E. (2009). A general equilibrium analysis of the impact of climate change on agriculture in the People's Republic of China. Asian Development Review, 26(1), 206-225.

Zidouemba, P. (2014). Sécurité alimentaire, productivité agricole et investissements publics au Burkina Faso : une analyse à l'aide d'un modèle d'Équilibre Général Calculable dynamique et stochastique. (PhD), CIRAD Montpellier SupAgro, UMR 1110 MOISA, Montpellier, France. Retrieved from http://prodinra.inra.fr/record/286982

\section{Appendix A}

Equations, variables and parameters of the cge model

\section{The production function}

$$
\begin{aligned}
& X D_{i, t}=\Omega_{i, t} \chi_{i}\left(\eta_{i} C I_{i, t}^{-\phi_{i}}+\left(1-\eta_{i}\right) V A_{i, t}^{-\phi_{i}}\right)^{-1} \phi_{i} \\
& \Omega_{\mathrm{i}, \mathrm{t}}=\left(\frac{I T P_{t}}{I T P_{t o}}\right)^{\xi_{i}} \\
& C I_{i, t}=\left(\frac{P D_{i, t}\left(1+t o_{i}\right)}{P I N P_{i, t}}\right)^{1 / 1+\phi_{i}} \chi_{i}^{-\phi_{i} / 1+\phi_{i}} \eta_{i}^{1 / 1+\phi_{i}} X D_{i, t} \\
& V A_{i, t}=\left(\frac{P D_{i, t}\left(1+t o_{i}\right)}{P V A_{i, t}}\right)^{1 / 1+\phi_{i}} \chi_{i}^{-\phi_{i} / 1+\phi_{i}} *\left(1-\eta_{i}\right)^{1 / 1+\phi_{i}} X D_{i, t} D I_{i, j, t}=i o_{i, j} C I_{i, t} \\
& P I N P_{i, t}=\sum_{j} i o_{i, j} P_{j, t}\left(1-\operatorname{tinp}_{i, j}\right) C I_{i, t}
\end{aligned}
$$




$$
\begin{aligned}
& A_{k, i, t}=\gamma_{i}^{-\mu_{i}} / 1+\mu_{i} * v^{1 / 1+\mu_{i}}\left(\frac{W_{k, i, t}+\lambda_{k, i, t}}{P V A_{i, t}}\right)^{-1 / 1+\mu_{i}} V A_{i, t} \\
& P V A_{k, i, t}=\frac{1}{\gamma_{i}}\left(\sum_{k} v_{k}^{1 / 1+\mu_{i}}\left(W_{k, i, t}+\lambda_{k, i, t}\right)^{\mu_{i} / 1+\mu_{i}}\right)^{1+\mu_{i} / \mu_{i}}
\end{aligned}
$$

\section{Factors' market}

The case of capital

$$
A_{k, i, t}=S A_{k, i, t}
$$

The case of labor

$$
\begin{aligned}
& \sum_{i \in \text { asec }} A_{k, i, t} \leq \sum_{i \in \text { asec }} S A_{k, i, t} \therefore \text { and } \therefore \sum_{i \in p \sec } A_{k, i, t} \leq \sum_{i \in p \sec } S A_{k, i, t} \\
& \text { and } \therefore \sum_{i \in \text { oind }} A_{k, i, t} \leq \sum_{i \in \text { oind }} S A_{k, i, t} \therefore \text { and } \therefore \sum_{i \in \text { osec }} A_{k, i, t} \leq \sum_{i \in \text { osec }} S A_{k, i, t}
\end{aligned}
$$

Unemployment rate

TXCHOM $=100 \frac{\sum_{i} S A_{k, i, t}-\sum_{i} A_{k, i, t}}{\sum_{i} S A_{k, i, t}}$

\section{Income, savings and final demand of households}

$Y_{h, t}=\left(1-t d_{h}\right) \sum_{k}$ endow $_{k, h} \sum_{i}\left(W_{k, i, t}+\lambda_{k, i, t}\right) A_{k, i, t}$

$+\sum_{h h}$ TRNHH $_{h, h h, t}+$ trngh $_{h, t} \mathrm{CPI}_{t}+$ trnwh $_{h, t}$ exr

$-\sum_{h h} T_{R N H H_{h h, h, t}}-T_{R N H} W_{h, t}$

$\operatorname{TRNHH}_{h, h h, t}=\left(\left(1-t d_{h}\right) \sum_{k} \operatorname{endow}_{k, h} \sum_{i}\left(W_{k, i, t}+\lambda_{k, i, t}\right) A_{k, i, t}\right) t h h_{h h, h}$

$\operatorname{TRNHW}_{h, t}=\left(\left(1-t d_{h}\right) \sum_{k} \operatorname{endow}_{k, h} \sum_{i}\left(W_{k, i, t}+\lambda_{k, i, t}\right) A_{k, i, t}\right) t w_{h}$

$H H S A V_{h, t}=\operatorname{mps}_{h} Y_{h, t}$

HHDEM $_{h, i, t}=$ cons $\min _{h, i, t}+$ conspar $_{h, i}\left(\left(1-\right.\right.$ mps $\left._{h}\right) Y_{h, t}-\sum_{i} P_{i, t}\left(1+t c_{i}\right)$ cons $\left.\min _{h, i, t}\right)$

Income and expenditures of the government

$G R_{t}=\sum_{i, h} P_{i, t} t c_{i} H H D E M_{h, i, t}+\sum_{i} P_{i, t} t i_{i} I N V_{i, t}+\sum_{i, j} P_{i, t} t_{i n p} D I_{i, j, t}$

$+\sum_{h} t d_{h} \sum_{k, h}$ endow $_{k, h}\left(W_{k, i, t}+\lambda_{k, i, t}\right) A_{k, i, t}-\sum_{i} P D_{i, t} t o_{i} X D_{i, j, t}$

$+\sum_{i} t m_{i} P W M_{i, t} M_{i, t}$ exr $+\sum_{i} t e_{i} P W E_{i, t} E_{i, t}$ exr + trnwgexr

$P_{i, t}$ GOVDEM $_{t}=\operatorname{gles}_{i}\left(\right.$ GR $_{t}-$ GOVSAV $_{t}-\sum_{h}$ trng $_{h}$ CPI $_{t}-$ trngwexr $)$

International trade and commodity price formation

$$
X_{i, t}=\sum_{j} D I_{i, j, t}+\sum_{h} \operatorname{HHDEM}_{h, i, t}+\operatorname{GOVDEM}_{i, t}+I N V_{i, t}
$$




$$
\begin{aligned}
& P_{i, t}=\frac{1}{\psi_{i}}\left(\left(1-\delta_{i}\right)^{1 / 1+o_{i}} P D_{i, t}^{o_{i} / 1+o_{i}}+\delta_{i}^{1 / 1+o_{i}} P M_{i, t}^{o_{i} / 1+o_{i}}\right)^{1+o_{i} / o_{i}} \\
& M_{i, t}=\left(\frac{P D_{i, t}}{P M_{i, t}}\right)^{1 / 1+o_{i}}\left(\frac{\delta_{i}}{1-\delta_{i}}\right)^{1 / 1+o_{i}} X X D_{i, t} \\
& P_{i, t} X_{i, t}=P D_{i, t} X X D_{i, t}+P M_{i, t} M_{i, t} \\
& C P I_{t}=\sum_{i} c w t s_{i} P_{i, t} \\
& P_{i, t} M_{i, t}=P W M_{i, t}\left(1+t m_{i}\right)(1+t x c o m) \text { exr } \\
& P_{i, t}=\frac{1}{\Lambda_{i}}\left(\left(1-\omega_{i}\right)^{-1 / \varphi_{i}-1} P D_{i, t}^{\varphi_{i} / \varphi_{i}-1}+\omega_{i}^{-1 / \varphi_{i}-1} P E_{i, t}^{\varphi_{i}} \varphi_{i}-1\right){ }^{\varphi_{i}-1 / \varphi_{i}} \\
& E_{i, t}=\left(\frac{\omega_{i}}{\left(1-\omega_{i}\right)}\right)^{1 / 1-\varphi_{i}}\left(\frac{P D_{i, t}}{P E_{i, t}}\right)^{1 / 1-\varphi_{i}} X X D_{i, t} P E_{i, t}=P W E_{i, t}\left(1-t e_{i}\right)\left(1-t x c o m_{i}\right) \operatorname{exr}
\end{aligned}
$$

\section{Equilibrium and closure}

$P_{i, t} X D_{i, t}=P D_{i, t} X X D_{i, t}+P E_{i, t} E_{i, t}, \quad \forall i \notin a \mathrm{sec}$

CURBAL $_{t}=\sum_{i} P E_{i, t} E_{i, t}+\sum_{h} t_{h} w h_{h, t}+t_{r n w g}$

$-\sum_{i} P M_{i, t} M_{i, t}-\sum_{h} t_{r n h} w_{h, t}-t r n g w_{t}$

$F S A V_{t}=-C U R B A L_{t}$

$I T_{t}=\sum_{h} H H S A V_{h, t}+G O V S A V_{t}+F S A V_{t} e x r$

$I T_{t}^{P R I}=I T_{t}-I T_{t}^{P U B}$

\section{Recursive dynamics}

$$
\begin{aligned}
& A_{k, i, t+1}=A_{k, i, t}\left(1-d e p_{i}\right)+I N D_{k, i, t} \\
& I T_{t}^{P U B}=P K_{t}^{P U B} \sum_{k, p u b} I N D_{k, p u b, t} \\
& I T_{t}^{P R I}=P K_{t}^{P R I} \sum_{k, p r i} I N D_{k, p r i, t} \\
& I T P_{t}=\tau I T_{t}^{P U B} \\
& I N D_{k, p r i, t}=\frac{\theta_{k, p r i} I T_{t}^{P R I}}{P K_{t}^{P R I}}
\end{aligned}
$$




$$
\begin{aligned}
& I N D_{k, p u b, t}=\frac{\theta_{k, p u b}(1-\tau) I T_{t}^{P U B}}{P K_{t}^{P U B}} \\
& P K_{t}^{P U B}=\frac{1}{A^{K_{-} P U B}} \prod_{i}\left[\frac{P_{i, t}}{\gamma_{i}^{I N V P U B}}\right]^{\gamma_{i}^{I N V P U B}} \\
& P K_{t}^{P R I}=\frac{1}{A^{K_{-} P R I}} \prod_{i}\left[\frac{P_{i, t}}{\gamma_{i}^{I N V P R I}}\right]^{\gamma_{i}^{I N P R I}} \\
& I N V_{i, t}=\text { imat }_{i} S A V I N G S_{t} \\
& S A_{\text {labor }, i, t+1}=S A_{\text {labor }, i, t}(1+\text { popgr }) \\
& \text { cons } \min _{h, i, t+1}=\text { cons } \min _{h, i, t}(1+\text { popgr })
\end{aligned}
$$

Sets

$\begin{array}{lll}\text { asec } & : & \text { Agricultural commodities } \\ h & : & \text { Households } \\ i & : & \text { Commodities and services } \\ j & : & \text { Activities } \\ k & : & \text { Factors of production } \\ \text { oind } & : & \text { Other industrial commodities } \\ \text { osec } & : & \text { Services } \\ \text { pri } & : & \text { Private activities } \\ \text { psec } & : & \text { Agrifood commodities } \\ \text { pub } & : & \text { Public activities }\end{array}$

Variables

$\begin{array}{lll}A k_{j} & : & \text { Amount of factor k used in the production of sector } \mathrm{j} \\ C I i & : & \text { Intermediate consumption demand of sector } \mathrm{i} \\ C P I & : & \text { Consumer price index } \\ C U R B A L & : & \text { Balance of payments } \\ D I i, j & : & \text { Intermediate demand of sector } \mathrm{j} \text { by sector } \mathrm{i} \\ E i & : & \text { Exports of commodity } \mathrm{i} \\ F S A V & : & \text { Foreign savings } \\ G O V D E M i & : & \text { Demand of the government for commodity } \mathrm{i} \\ G O V S A V & : & \text { Public savings } \\ G R & : & \text { Government revenue } \\ H H D E M i, h & : & \text { Quantity of commodity i consumed by household } \mathrm{h} \\ H H S A V h & : & \text { Household h savings } \\ I N D k, j, t & : & \text { Volume of new type k capital investment to sector } \mathrm{j} \\ I N V i & : & \text { Investment demand of commodity } \mathrm{i} \\ I T P t & : & \text { New infrastructure investment } \\ I T t & : & \text { Total investment expenditures } \\ I T_{t}^{P R I} & : & \text { Total private investment expenditures } \\ I T_{t}^{P U B} & : & \text { Total public investment expenditures } \\ M_{i} & : & \text { Imports of commodity i } \\ P D_{i} & : & \text { Domestic price of commodity } \mathrm{i} \\ P E_{i} & : & \text { Export price at local currency of commodity } \mathrm{i} \\ P_{i} & : & \text { Composite price of commodity } \mathrm{i} \\ P I N P_{i} & : & \text { Price of intermediate consumption of activity } \mathrm{i} \\ P K_{t}^{P R I} & : & \text { Price of new private capital } \\ P K_{t}^{P U B} & : & \text { Price of new public capital } \\ & & \end{array}$




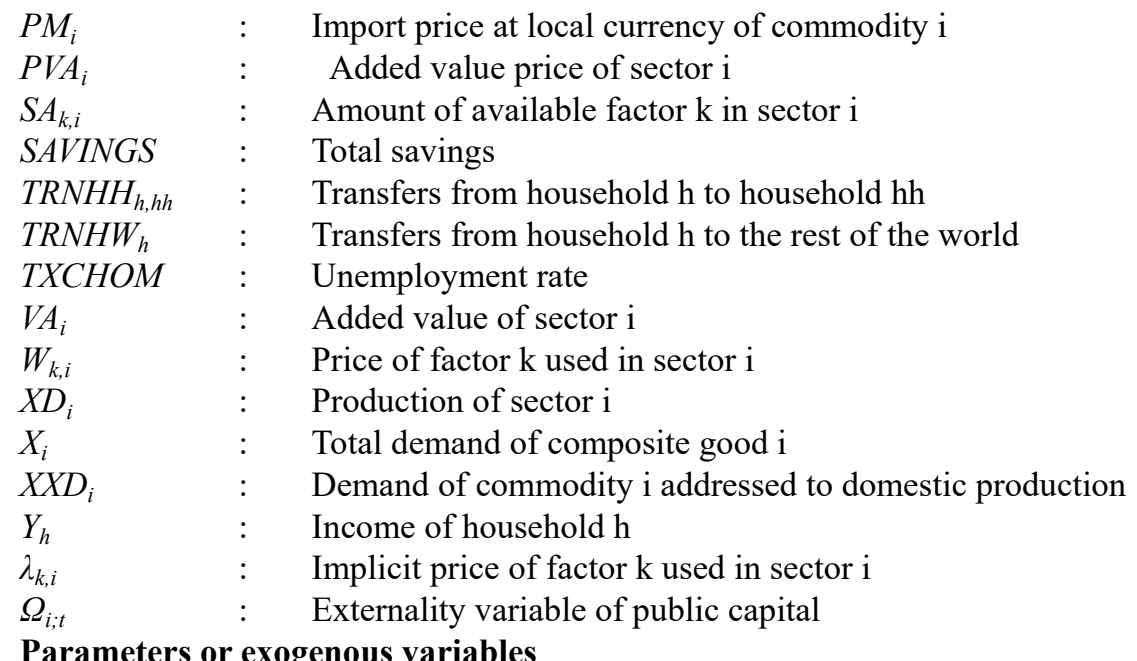

$A K P R I \quad$ : $\quad$ Scale parameter (price of new private capital)

$A K \_$PUB : $\quad$ Scale parameter (price of new public capital)

Consmin $_{h, i} \quad: \quad$ Minimum consumption of commodities in the LES demand equations

conspar $_{h, i} \quad$ : $\quad$ Marginal share of commodity $i$ in the type $h$ household consumption budget

$c w t s_{i}$

$\operatorname{dep}_{i}$

Weight of commodity $\mathrm{c}$ in the consumer price index

endow

Capital depreciation rate

exr : Nominal exchange rate

gles $_{i} \quad: \quad$ Share of commodity i government consumption

imat $_{i} \quad$ : Matrix of investment goods

$i o_{i, j} \quad: \quad$ Input/output coefficient

mpsh : Marginal propensity to save

popgr : Population growth rate

$t c_{i, h}$

$t d_{h}$

te

$t h h_{h h, h}$

$t i_{i}$

$\operatorname{tinp}_{i, j}$

$\mathrm{tm}_{i}$

to ${ }_{i}$

trngh

trngw

$t w_{h}$

txcom $_{i}$

$\gamma_{i}, v_{i}, \mu_{i}$

$\gamma_{i}^{I N V P R I}$

$\gamma_{i}{ }_{i N V P U B}$

$\theta_{k, i}$

$\Lambda_{i}, \omega_{i}, \varphi_{i}$

$\xi_{i}$

Tax rate on the consumption of commodity $i$

Direct tax rate on the income of household $h$

Tax rate on exports of commodity $i$

Share of household hh income transferred to the household $h$

Tax rate on investment demand for commodity $i$

Tax rate on intermediate demand by sector $\mathrm{j}$ for commodity $\mathrm{i}$

Tax rate on imports of commodity $i$

Tax rate on the production of commodity $i$

Government transfers to household $h$

Government transfers to the rest of the world

share of household hh income transferred to the rest of the world

Import transaction cost for commodity $\mathrm{i}$

CES function parameters aggregating the different factors of production

Share of commodity $i$ in total private investment expenditure

Share of commodity $i$ in total public investment expenditure

Investment allocation coefficient between sectors

CET function parameters aggregating exports and domestic commodities $\mathrm{i}$

Sector-specific elasticity with respect to public capital

$\tau \quad: \quad$ Share of total public investment amount allocated to infrastructure spending

$\chi_{i}, \eta_{i}, \phi_{i} \quad$ : CES function parameters aggregating VA and intermediate inputs in sector $\mathrm{i}$

$\psi_{i}, \delta_{i}, o_{i} \quad$ CES function parameters aggregating imports and domestic commodities $\mathrm{i}$

\section{Copyrights}

Copyright for this article is retained by the author(s), with first publication rights granted to the journal.

This is an open-access article distributed under the terms and conditions of the Creative Commons Attribution license which permits unrestricted use, distribution, and reproduction in any medium, provided the original work is properly cited. 